УДК 616·314·8:616:314-089·23

Дорошенко С.I., Кузьменко І.С., Стороженко К.В. ${ }^{1}$, Ірха С.В., Демянчук Х.М. ДИФЕРЕНЦІЙОВАНИЙ ПІДХІД ДО ЗБЕРЕЖЕННЯ ТРЕТІХ МОЛЯРІВ
У ОРТОДОНТИЧНИХ ПАЦІЄНТІВ

ПВНЗ «Київський медичний університет», Київ, Україна

${ }^{1}$ Національний медичний університет імені О.О. Богомольця, Київ, Україна

\section{Актуальність}

Жодні зуби не створюють стільки проблем для пацієнтів, а також і лікарів, як треті моляри. Прорізуючись пізніше всіх зубів, найчастіше вони мають мало місця в зубному ряду, а точніше - у ретромолярному просторі, який має утворитися перш за все лише за умови подальшого росту щелеп [1;2]. Тому терміни їх прорізування широко варіюють і супроводжуються нерідко появою значних і морфологічних, і фрункціональних порушень. Недарма їх називають зубами «мудрості». При цьому виникає низка ускладнень (перикоронарит, періостит, остеомієліт, лімфаденіт, абсцес, фрлегмона, стійка ретенція), що потребує досить складних хірургічних втручань, які залежать від стану прилеглих тканин і самого зуба: його форми й величини, форми коренів, положення в щелепі, напрямку прорізування тощо [3-7].

Деякі автори пов'язують проблему зубів мудрості з процесом фрілогенетичної редукції жувального апарату, пояснюючи тим, що наші предки мали до 42 - 44 зубів, бо їли тверду, термічно необроблену їжу й мали щелепи більших розмірів $[8 ; 9]$.

Форма й величина зуба мудрості варіабельніша, ніж інших, особливо верхніх молярів, а також він більше схильний до аномалій, ніж будьякий зуб щелепи. Ці аномалії стосуються не тільки коронки, а й кореня; [1] розрізняв у цьому процесі чотири стадії: I стадія пояснюється видозміною верхнього зуба мудрості від маленького конуса до повного розвитку моляра, тобто зуб ніби бореться за свою форму, втрата якої неминуча; II - зуб повністю втрачає свою первісну форму, й конічна фрорма встановлюється; III зуб перетворюється в маленький рудиментарний утвір, який у щелепі не відіграє жодної ролі. На всіх цих стадіях третій моляр має коронку 3 коренем і емалевий по́крив на коронці. На IV стадії емаль відсутня, а зародки часто перетворюються в неправильної форми тільця. [3] виділив ще одну стадію, в якій зуб може мати вигляд м'якого утвору, i, можливо, в майбутньому, як вважає він, у людини зубна формула буде складатися із 28 зубів, що останнім часом нерідко підтверджується [5-8].

На підставі цього деякі науковці розглядають треті моляри як рудиментарні структури зубощелепного апарату людини, припускаючи, що морфофункціональна недостатність третіх молярів із часом призведе до зниження їхньої карієсорезистентності. Ураховуючи цей фракт, М.І. Агапов при розрахунку жувальної ефективності треті моляри не враховував. Натомість І.М. Оксман надавав їм не меншого значення в реалізації жувальної функції людини, а саме: нижнім $4 \%$, а верхнім - 3\%.

Закладка зародків третіх молярів, зокрема на НЩ, відбувається в 5 років на межі переходу альвеолярної частини в гілку, тобто в ділянці нижньощелепного кута. За час зміни тимчасових зубів щелепи подовжуються, тобто ростуть, забезпечуючи місце для прорізування першого i другого постійних молярів. Другий моляр, прорізуючись, займає весь ретромолярний простір, не залишаючи місця для прорізування третіх молярів. Якщо у віці $16-20$ років не продовжуватиметься ріст щелепи, це слугуватиме причиною їх стійкої ретенції [10-11].

Проте, як показала практика, наявність третіх молярів у людини має не менше значення, особливо за умови їх правильного розташування в щелепах, бо іноді вони залишаються єдиною дистальною опорою при компенсації дефекту зубного ряду в боковій ділянці [12].

Тому важливо виважено підходити до вирішення питань щодо збереження в зубному ряду третіх молярів шляхом своєчасного виявлення їхнього стану, а також положення в щелепних кістках (форми їхніх коронок і коренів, нахил поздовжньої осі відносно основи щелеп і нахил других постійних молярів тощо), що і стало предметом проведених нами досліджень.

\section{Мета дослідження}

Обґрунтувати диференційований підхід до збереження третіх молярів при ортодонтичному лікуванні шляхом визначення їхнього стану й положення в щелепі.

\section{Матеріал і методи досліджень}

Нами було взято на лікування й обстежено 44 пацієнти віком від 15 до 30 років із різними зубощелепними аномаліями, в яких, за даними клінічних і рентгенологічних досліджень, був повний комплект постійних зубів, включаючи треті моляри. У всіх пацієнтів вимірювали діагностичні моделі й аналізували їх методами A. Pont (ширина зубних дуг) і G. Korkhaus (довжина зубних дуг). Окрім того, вимірювали ретромолярний 
простір для визначення наявності місця третім молярам у зубному ряду (його параметри за протяжністю й висотою).

Рентгенологічні дослідження охоплювали аналіз ортопантомограм (ОПТГ), телерентгенограми (ТРГ), комп'ютерну томографрію (КТ). ОПТГ аналізували за методикою К.В. Стороженко (2017): вимірювали осьовий нахил зубів відносно основи щелепи, зокрема третіх і других молярів, а також визначали різниці в їхніх нахилах (рис. 1).

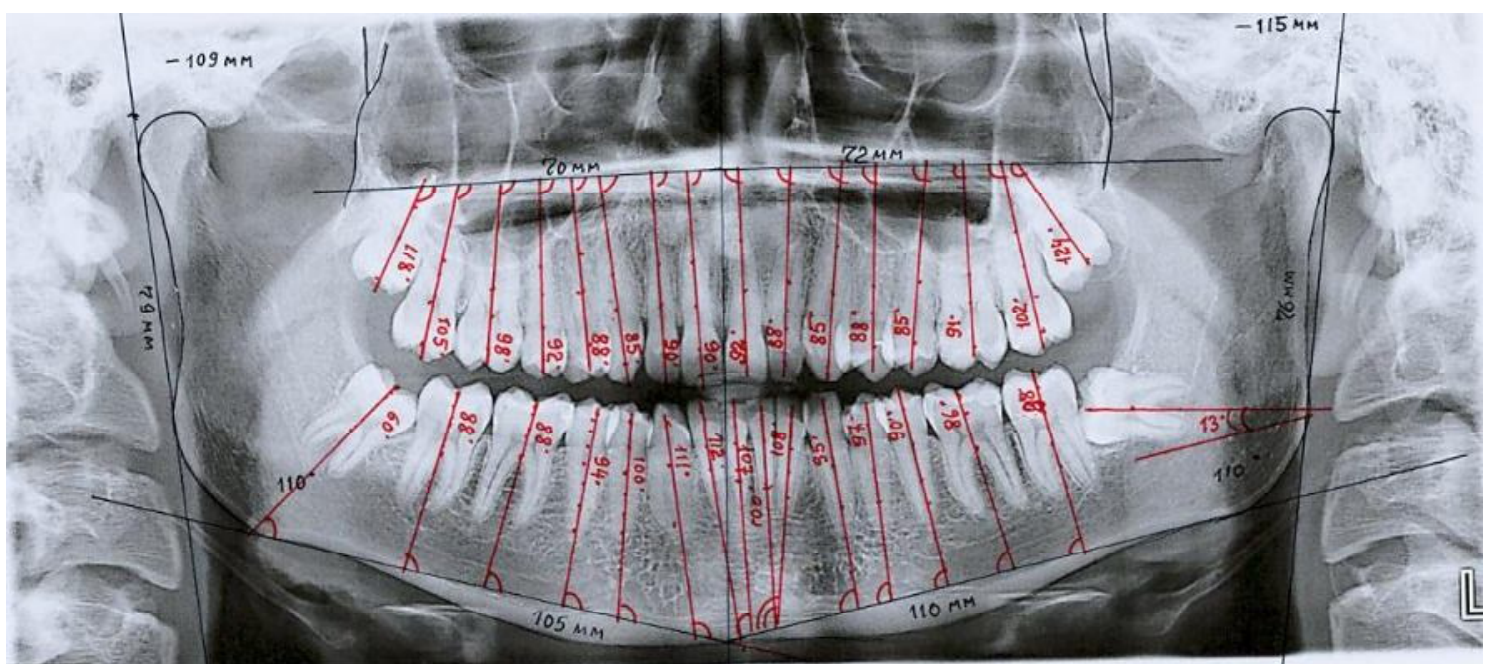

Рис. 1. Вимірювання нахилу зубів до основи щелеп за методикою К.В. Стороженко

Особливої уваги надавали вимірюванням кутів нахилу третіх і других молярів та їх співвідношенню між собою з обох боків, тобто ліворуч і праворуч на обох щелепах.
Окрім того, визначали дефіцит місця в ретромолярному просторі для прорізування третіх молярів у разі їх ретенції за методикою С.І. Дорошенко і Є.А. Кульгінського (2009) (рис. 2).

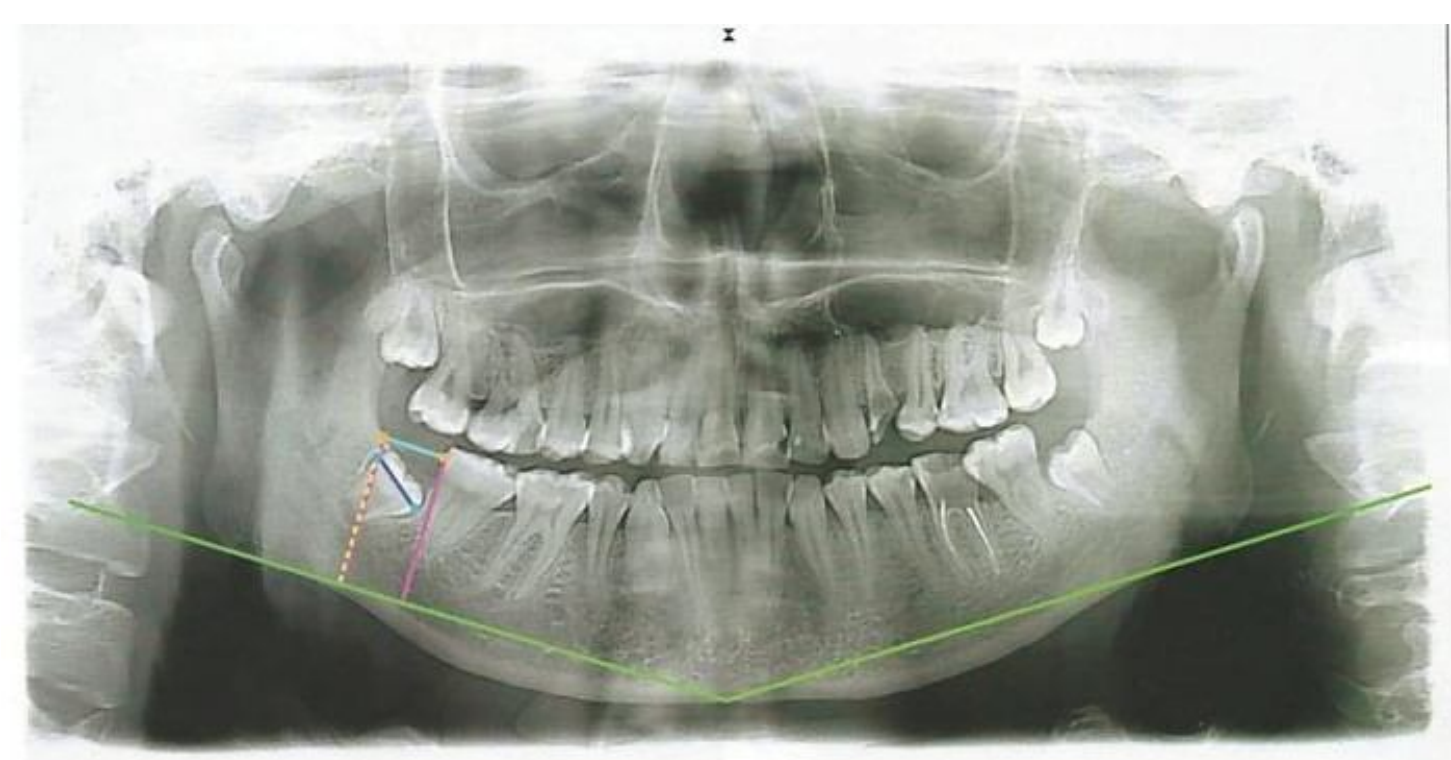

Puc.2. Вимірювання протяжності ретромолярного простору, тобто по сагіталі, за методикою С.І. Дорошенко і Є.А. Кульгінського

Дефріцит місця в зубній дузі по сагіталі для третіх молярів за даною методикою визначали на ортопантомограмі за такими орієнтирами: від найбільш випнутих точок на дистальній поверхні коронок других молярів, що розташовані в зубній дузі, та дистальних поверхонь ретенованих третіх молярів виставляли перпендикуляри на відповідних їм площинах щелеп (MP та SpP). Після цього вимірювали відстань між перпендикулярами, яку зіставляли з шириною коронки третьо- го моляра (ретенованого чи того, що прорізується). Різниця в цих величинах свідчила про десріцит місця для третього моляра в ретромолярному просторі, тобто його протяжність (по сагіталі). Висоту ретромолярного простору, тобто міжальвеолярну відстань (вертикальну щілину) в бокових ділянках вимірювали по силіконових шаблонах, отриманих у центральній оклюзії (по товщині силіконової маси між альвеолярними відростками (рис. 3). 

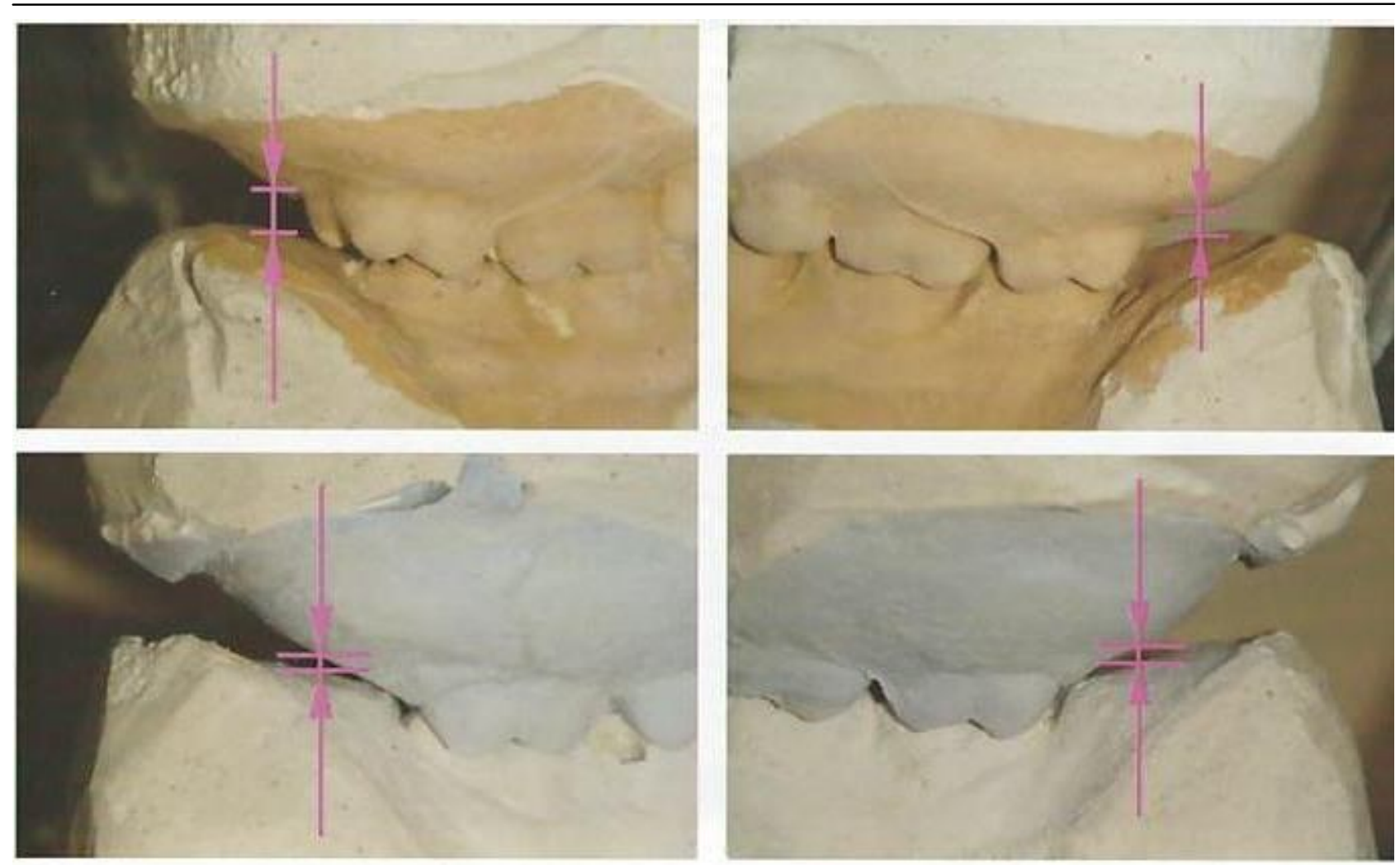

Рис.3. Вимірювання висоти ретромолярного простору, тобто по вертикалі, за методикою C.I. Дорошенко і Є.А. Кульгінського

У процесі обробки цих вимірювань застосували методи математичної статистики. Для кожного параметра вимірювали й неодноразово обчислювали середнє значення і довірчий інтервал із вибірки даних. Середнє значення й довірчий інтервал вибірки даних розраховували за вимогами стандарту ГОСТ Р 8.736-2011.

Вибіркове середнє обчислювали як середнє арифметичне елементів групи. Довірчий інтервал $\varepsilon$ визначали таким чином:

$\varepsilon=\mathrm{ts}$,

де $\mathrm{t}$ - коефіцієнт Стьюдента, $\mathrm{s}$ - середньоквадратичне відхилення результатів вимірювання. Коефіцієнт Стьюдента визначали за таблицями залежно від кількості даних $\mathrm{n}$ і рівня довіри р. При обчисленні довірчого інтервалу був прийнятий рівень довіри $p=0,95$.

Середньоквадратичне відхилення оцінювали як стандартне відхилення випадкової величини від вибіркового середнього за формулою:

$$
s=\sqrt{\frac{s_{l=1}^{n}(x i-x c)}{n(n-1)}}
$$

\section{Результати досліджень}

Дані вимірювання осьового нахилу других i третіх молярів засвідчили наступне. Нахили третіх молярів на верхній щелепі (ВЩ) варіювали ліворуч від $72^{\circ}$ до $146^{\circ}$ із середнім значенням $115,7^{\circ} \pm 5,5^{\circ}$, а праворуч - від $71^{\circ}$ до $140^{\circ}$ із середнім значенням $116,8^{\circ} \pm 4,9^{\circ}$, тобто різниця в нахилах ліворуч і праворуч складала в середньому $1,1^{\circ} \pm 0,6^{\circ}$. Нахили других молярів на ВЩ ліворуч варіювали від $82^{\circ}$ до $126^{\circ}$ із середнім значенням $104,3 \pm 3,3$, а праворуч - від $82^{\circ}$ до $126^{\circ}$ із середнім значенням $103,8 \pm 3,6$, тобто різниця в нахилах ліворуч і праворуч становила $0,5^{\circ} \pm 0,3^{\circ}$. Різниця в нахилах третіх і других молярів на ВЩ ліворуч становила від $2^{\circ}$ до $58^{\circ}$, у середньому $15,6^{\circ} \pm 3,3^{\circ}$, а праворуч - від $0^{\circ}$ до $55^{\circ}$, у середньому $19,2^{\circ} \pm 3,5^{\circ}$, тобто різниця в нахилах третіх і других молярів праворуч і ліворуч на ВЩ складала $3,6^{\circ} \pm 0,2^{\circ}$.

На нижній щелепі (НЩ) нахили третіх молярів варіювали ліворуч - від $0^{\circ}$ до $128^{\circ}$ із середнім значенням $62,1^{\circ} \pm 8,4^{\circ}$, а праворуч - від $17^{\circ}$ до $129^{\circ}$ із середнім значенням $68,2^{\circ} \pm 8,9^{\circ}$, тобто різниця в нахилах ліворуч і праворуч складала $6,1^{\circ} \pm 0,5^{\circ}$. Нахили других молярів на НЩ ліворуч варіювали від $62^{\circ}$ до $102^{\circ}$ із середнім значенням $81,5^{\circ} \pm 2,6^{\circ}$, а праворуч - від $60^{\circ}$ до $104^{\circ}$ із середнім значенням $82,8^{\circ} \pm 3^{\circ}$, тобто різниця в нахилах ліворуч і праворуч становила $1,3^{\circ} \pm 0,4^{\circ}$. Різниця в нахилах третіх і других молярів на НЩ ліворуч становила від $2^{\circ}$ до $79^{\circ}-$ в середньому $30,3^{\circ} \pm 5,7^{\circ}$, а праворуч - від $0^{\circ}$ до $75^{\circ}$, у середньому $30,0^{\circ} \pm 5,9^{\circ}$, тобто різниця в нахилах третіх і других молярів ліворуч і праворуч на НЩ складала $0,3^{\circ} \pm 0,2^{\circ}$ (табл.1).

Отже, найбільша різниця в нахилах третіх $\mathrm{i}$ других молярів спостерігалася на НЩ і ліворуч, i праворуч із незначним відхиленням $0,3^{\circ} \pm 0,2^{\circ}$. Найменша різниця в нахилах третіх і других молярів виявилася на ВЩ, особливо ліворуч, але 3 більшим відхиленням $-3,6^{\circ} \pm 0,2^{\circ}$. 
Різниця в нахилах третіх і других молярів на ВЩ і НЩ ліворуч і праворуч

\begin{tabular}{|c|c|c|c|}
\hline \multicolumn{2}{|c|}{ Верхня щелепа } & \multicolumn{2}{c|}{ Нижня щелепа } \\
\hline ліворуч & праворуч & ліворуч & праворуч \\
\hline $15,6^{\circ} \pm 3,3^{\circ}$ & $19,2^{\circ} \pm 3,5^{\circ}$ & $30,3^{\circ} \pm 5,7^{\circ}$ & $30,0^{\circ} \pm 5,9^{\circ}$ \\
\hline \multicolumn{2}{|c|}{$3,6^{\circ} \pm 0,2^{\circ}$} & $0,3^{\circ} \pm 0,2^{\circ}$ \\
\hline
\end{tabular}

Проведені дослідження показали, що чим більша різниця в нахилах третіх нижніх молярів відносно других молярів, тим більше проблем у їх прорізуванні, оскільки вони прорізуються пізніше, а другі моляри мають сприятливіші умови для прорізування й оптимально правильного нахилу відносно основи щелепи. Отримані дані вимірювання осьових нахилів третіх молярів засвідчили те, що нижні треті моляри, як правило, нахиляються коронковими частинами медіально, тому мають менші значення кутів нахилу відносно основи НЩ. Натомість верхні треті моляри при прорізуванні нахилені коронковими части- нами дистально зі збільшенням величини нахилу кутів відносно основи ВЩ. Так, на ВЩ кут нахилу третіх молярів від $100^{\circ}$ до $146^{\circ}$ спостерігався в 37 осіб ліворуч і в 37 осіб праворуч, що складає від загальної кількості обстежених 44 пацієнтів відповідно 89,09\% і 89,09\%. На НЩ кут нахилу третіх молярів від $11^{\circ}$ до $60^{\circ}$ спостерігався у 24 осіб ліворуч і у 20 пацієнтів - праворуч, що відповідає у відсотковому співвідношенні $54,5 \%$ і 45,5\%. Лише в одного пацієнта третій моляр на НЩ ліворуч мав нахил $0^{\circ}$, тобто вісь нахиленого зуба була паралельна площині основи щелепи (рис. 4; 5).

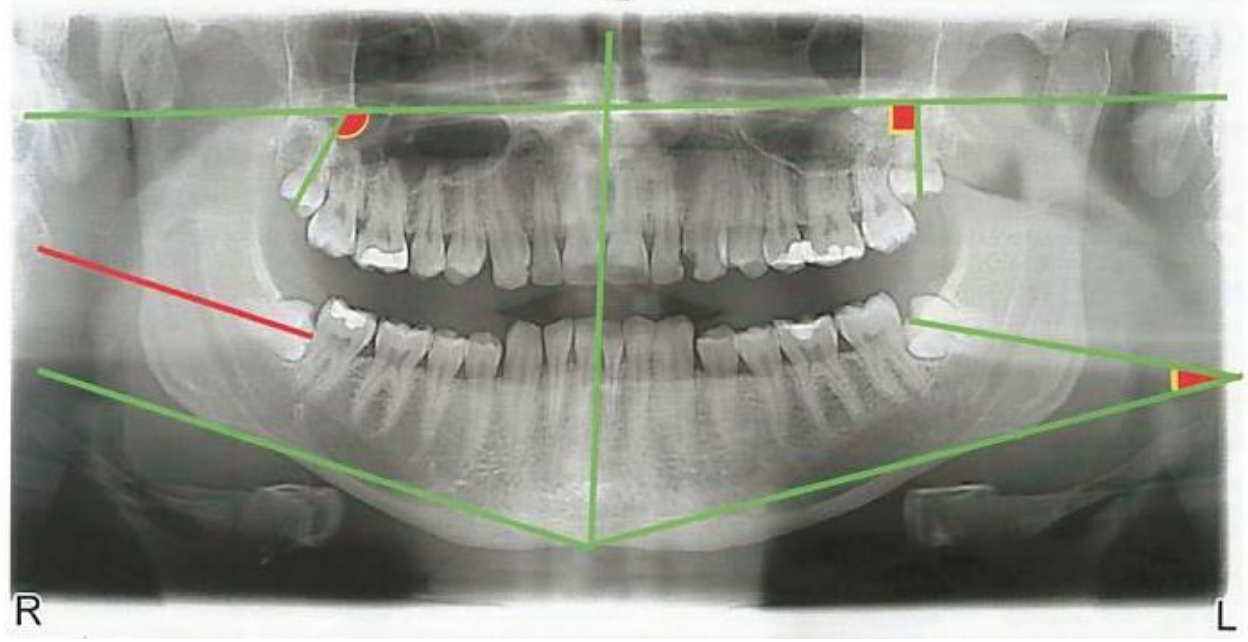

Pис.4. Вимірювання нахилу третіх молярів у пацієнта P., 21 р.

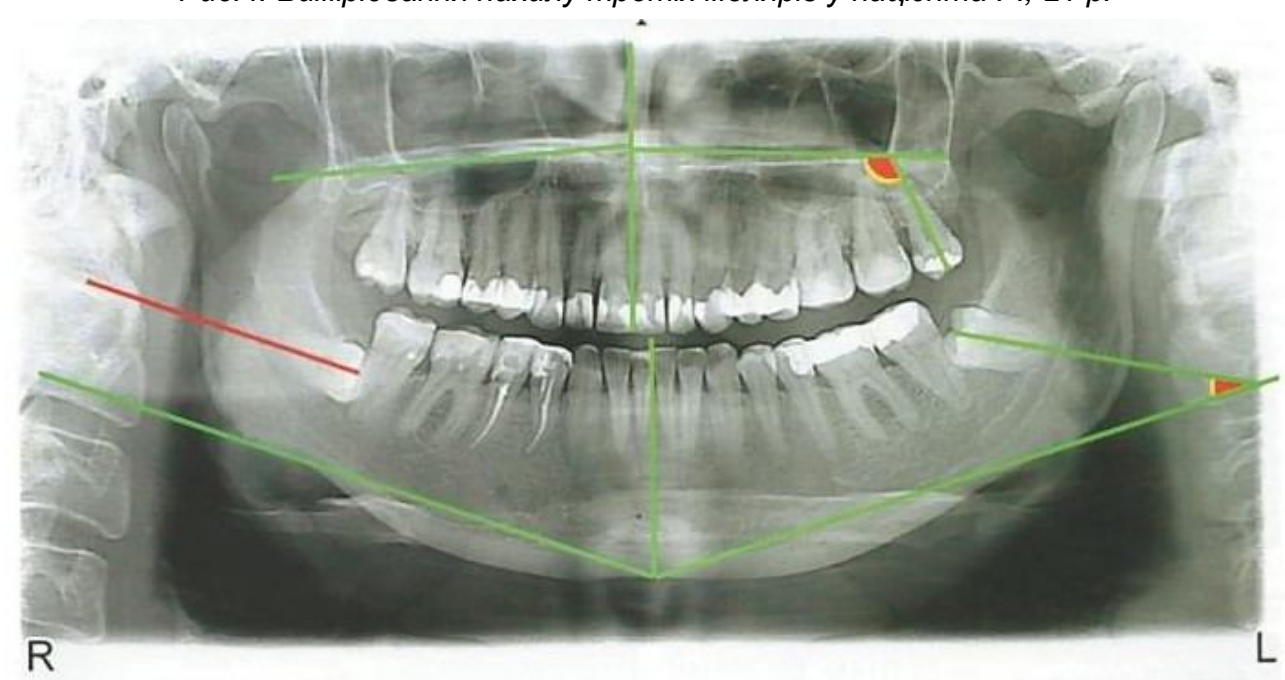

Рис.5. Вимірювання нахилу третіх молярів у пацієнта Л., 30 p.

Наведені вище показники нахилу третіх молярів свідчать певним чином про найбільш несприятливі умови для їх прорізування. Дані аналізу ОПТГ показали, що в 44 пацієнтів віком від 15 до 30 років $106(60,2 \%)$ третіх молярів знаходилися в стані ретенції, із них: 35 (33,1\%) - у стані фрізіологічної ретенції, переважно в осіб молодшого віку. Різниця в основних нахилах 2-х і 3-х молярів у цій групі була $12,6 \pm 3,2^{\circ}$. У положенні напівретенції (частково прорізалися) було $40(37,7 \%)$ зубів. Різниця в кутах нахилу була $15,4 \pm 4,2^{\circ}$. У стійкій ретенції було $31(29,2 \%)$ зубів, різниця в кутах нахилу становила $19,6 \pm 6,1^{\circ}$.

Тому велике значення в прогнозі прорізуван- 
ня мала наявність місця для зубів мудрості в ретромолярному просторі й по сагіталі, і по вертикалі, що визначалося за методикою С.І. Дорошенко і Є.А. Кульгінського, тобто за силіконовими шаблонами, які відображали стан ретромолярного простору. Дані вимірювання дефіциту місця для третіх молярів у зубному ряду, тобто по сагіталі, показали, що місце було лише у 25 $(14,2 \%)$ зі 176 зубів мудрості, із них у 15 (8,5\%) на НЩ, зокрема в 7 (4,0\%) молярів - на НЩ ліворуч, а праворуч - у 8 (4,5\%). На ВЩ - 10 $(5,7 \%)$ молярів мали достатнє місце, зокрема 6 (3,4\%) ліворуч і 4 (2,3\%) праворуч.

Наявність місця в зубному ряду для зуба мудрості залежала й від його ширини в ділянці екватора. Як показали дані вимірювання, ширина третіх молярів у ділянці екватора виявилася найменшою на ВЩ і варіювала від 10 мм до 15 мм, із середнім значенням 11,7 мм, а найбільшою - на НЩ - від 12 мм до 19 мм, із середнім значенням 14,17 мм. Різниці середніх значень у розмірах між правими й лівими молярами на ВЩ не виявлено: 11,8 мм і 11,8 мм відповідно, а на НЩ вона була незначною - 14,2 мм і 14,1 мм, тобто всього 0,1 мм. Разом із тим, в окремих випадках різниця складала 2,0 - 4,0 мм - на ВЩ і всього 1,0 мм - на НЩ. Останнє підтверджує висновки деяких учених-дослідників, що верхні треті моляри більш варіабельні в розмірах, оскільки саме вони найчастіше бувають аномальної шилоподібної форми, що свідчить, на думку авторів, про процес філогенетичної редукції зубощелепного апарату в людини, який триває.

Дані клінічних досліджень показали, що ретенція третіх молярів у обстежених відбувалася на тлі різних зубощелепних аномалій. Найчастіше при дистальному (II клас) - у 17 (38,6\%) осіб і глибокому $13(29,5 \%)$ прикусах, рідше - при мезіальному (III клас) - 4 (9,1\%) осіб і відкритому у $4(9,1 \%)$ пацієнтів. Нейтральний прикус (за правильного співвідношення перших молярів) виявлено в 6 (13,6\%) осіб.

Найпоширенішою аномалією положення окремих зубів серед 44 обстежених була скупченість, особливо нижніх фронтальних зубів - у $21(47,8 \%)$ пацієнта. Вестибулярне положення зубів, переважно іклів, спостерігалося в 11 $(25,0 \%)$ осіб, лінгвальне (оральне) положення у $8(18,2 \%)$, повороти зубів навколо осі - у 7 (15,5\%) обстежених. Треми й діастеми траплялися досить рідко - у 2 (4,5\%). Слід зазначити, що більшість оглянутих помічали появу й посилення скупченості зубів із віком, особливо після 18 років. Це пов'язано, на наш погляд, із тим, що зуби мудрості починали проявляти свою потенцію до прорізування. Проте, як відомо, не всі 3 них змогли прорізалися за об'єктивних причин, а саме: аномалії закладки їхніх зачатків і дефріцит місця в зубному ряду.

Проведені клінічні дослідження показали, що при виборі тактики лікування ретенованих зубів мудрості важливо поряд із вивченням їх положення в щелепних кістках і наявності місця в зу- бному ряду (по сагіталі) визначити також величину міжальвеолярного простору на ділянці ретенованих молярів за вертикаллю. За даними вимірювання на силіконових шаблонах, міжальвеолярний простір за вертикаллю варіював від 0,5 мм до 7 мм. В осіб із глибоким і дистальним прикусом цей міжальвеолярний простір був у межах 0,5 мм - 4 мм, тоді як при нейтральному прикусі - від 5 мм до 7 мм.

\section{Висновки}

Треті моляри відіграють, як і інші зуби, важливу роль у фрормуванні зубоще́лепного апарату людини: забезпечують цілісність і опору зубних рядів, а також їхню жувальну ефективність; стимулюють подальший ріст щелеп при прорізуванні, завершуючи останній (четвертий) етап становлення висоти прикусу, та найголовніше - слугують іноді єдиною надійною дистальною опорою при компенсації ДЗР у бокових ділянках незмінними конструкціями. Тому слід обережно ставитися до видалення третіх молярів.

Основними показаннями до збереження зубів мудрості, особливо при ортодонтичному лікуванні пацієнтів зі ЗЩА, слугують: положення і стан їх у щелепі (фізіологічна, стійка або напівретенція), кут нахилу до основи щелепи і других молярів; наявність місця в зубному ряду за протяжністю (по сагіталі) і висотою ретромолярного простору, тобто по вертикалі.

При цьому велике значення має ширина коронкової частини зуба на ділянці екватора. Найширшу варіабельність у розмірах мали треті моляри на ВЩ, у них частіше спостерігалася шилоподібна форма коронки, що пов'язано 3 процесом фрілогенетичної редукції зубощелепного апарату.

Найчастіше ретенцію зубів мудрості мали пацієнти з дистальним (II клас) - 38,6\% і глибоким прикусом - 29,5\%, але рідше - при нейтральному прикусі - 13,6\%. Серед аномалій положення окремих зубів превалювала скупченість, особливо фронтальних зубів $(47,8 \%)$, яка прогресувала в період прорізування третіх молярів.

Ступінь ретенції зростає зі збільшенням різниці кутів нахилу других і третіх молярів.

\section{Список літератури}

1. Baume R. Ueber das Verhalten der Substant. Spongiosa b.patol. Processen m.d. Alveolen der Kieferknochen. Dentsche Viesteljahrssch; 1871. $158 \mathrm{p}$.

2. Говсеева ЛА. Руководство к лечению зубных болезней. Венский университет. І. 1898. 158 с.

3. Rafetto LK. Managing Impacted Third Molars. 2015 Aug;27(3):363-71.

4. Martin B Steed. The indications for third-molar extractions. J Am Dent Assoc. 2014 Jun;145(6):570-3.

5. Henriksson $\mathrm{CH}$, Andersson M, Moystad A. Hypodontia and retention of third molars in Norwegian medieval skeletons: dental radiography in osteoarchaeology. Acta Odontol Scand. 2019 May;77(4):310-4. 
6. Rivera-Herrera RS, Esparza-Villalpando V, BermeoEscalona JR, Martínez-Rider R, Pozos-Guillén A. Agreement analysis of three mandibular third molar retention classifications. Gac Med Mex. 2020;156(1):22-6.

7. Zhang Y, Leveille SG, Edward J. Wisdom teeth, periodontal disease, and C-reactive protein in US adults. Public Health. 2020 Oct;187:97-102.

8. Lanzer M, Pejicic R, Kruse AL, Schneider T, Grätz $\mathrm{KW}$. Anatomic (positional) variation of maxillary wisdom teeth with special regard to the maxillary sinus. Swiss Dent J. 2015;125(5):555-71.

9. Machtei EE, Hirsch I. Retention of hopeless teeth: the effect on the adjacent proximal bone following periodontal surgery. J Periodontol. 2007 Dec;78(12):2246-52.

10. Zhang W, Chen X, Fan M, Mulder J, Frencken JE. Retention Rate of Four Different Sealant Materials after Four Years. Oral Health Prev Dent. 2017;15(4):307-14.

11. Wake R, Buck R, DuVall N, Roberts H. Effect of Molar Preparation Axial Height on Retention of Adhesively-luted CAD-CAM Ceramic Crowns. J Adhes Dent. 2019;21(6):545-50.

12. Song F, O'Meara S, Wilson P, Golder S, Kleijnen J. The effectiveness and cost-effectiveness of prophylactic removal of wisdom teeth. Health Technol Assess. 2000;4(15):1-55.

\section{References}

1. Baume R. Ueber das Verhalten der Substant. Spongiosa b.patol. Processen m.d. Alveolen der Kieferknochen. Dentsche Viesteljahrssch; 1871. 158 p.

2. Govseeva LA. Rukovodstvo k lecheniyu zubny'kh boleznej. Venskij univer-sitet. I. 1898. 158 p. (Russian).

3. Rafetto LK. Managing Impacted Third Molars. 2015 Aug;27(3):363-71.
4. Martin B Steed. The indications for third-molar extractions. J Am Dent Assoc. 2014 Jun;145(6):570-3.

5. Henriksson $\mathrm{CH}$, Andersson M, Moystad A. Hypodontia and retention of third molars in Norwegian medieval skeletons: dental radiography in osteoarchaeology. Acta Odontol Scand. 2019 May;77(4):310-4.

6. Rivera-Herrera RS, Esparza-Villalpando V, BermeoEscalona JR, Martínez-Rider R, Pozos-Guillén A. Agreement analysis of three mandibular third molar retention classifications. Gac Med Mex. 2020;156(1):22-6.

7. Zhang Y, Leveille SG, Edward J. Wisdom teeth, periodontal disease, and C-reactive protein in US adults. Public Health. 2020 Oct;187:97-102.

8. Lanzer M, Pejicic R, Kruse AL, Schneider T, Grätz $\mathrm{KW}$. Anatomic (positional) variation of maxillary wisdom teeth with special regard to the maxillary sinus. Swiss Dent J. 2015;125(5):555-71.

9. Machtei EE, Hirsch I. Retention of hopeless teeth: the effect on the adjacent proximal bone following periodontal surgery. J Periodontol. 2007 Dec;78(12):2246-52.

10. Zhang W, Chen X, Fan M, Mulder J, Frencken JE. Retention Rate of Four Different Sealant Materials after Four Years. Oral Health Prev Dent. 2017; 15(4):307-14.

11. Wake R, Buck R, DuVall N, Roberts H. Effect of Molar Preparation Axial Height on Retention of Adhesively-luted CAD-CAM Ceramic Crowns. J Adhes Dent. 2019;21(6):545-50.

12. Song F, O'Meara S, Wilson P, Golder S, Kleijnen J. The effectiveness and cost-effectiveness of prophylactic removal of wisdom teeth. Health Technol Assess. 2000;4(15):1-55.

Стаття надійшла: 24.02.2021 p.

\section{Резюме}

Жодні зуби не створюють стільки проблем для пацієнтів, а також лікарів, як треті моляри. Прорізуючись пізніше всіх зубів, найчастіше вони мають мало місця в зубному ряду, а точніше - у ретромолярному просторі, який має утворитися за умови, перш за все, подальшого росту щелеп. Тому терміни їх прорізування широко варіюють і супроводжуються нерідко появою значних і морфологічних, і функціональних порушень. Ось чому необхідно виважено підходити до вирішення питань щодо збереження в зубній дузі третіх молярів, забезпечивши їм місце в ретромолярному просторі шляхом своєчасного виявлення їхнього стану й положення в щелепних кістках, і цим самим зберегти цілісність зубних рядів та реалізувати четвертий, останній етап підвищення висоти прикусу при ортодонтичному лікуванні пацієнтів із зубощелепними аномаліями. 3 цією метою було обстежено і взято на ортодонтичне лікування 44 пацієнтів віком від 15 до 30 років із різними зубощелепними аномаліями, в яких, за даними клінічних і рентгенологічних досліджень, був повний комплект постійних зубів, включаючи треті моляри. ОПТГ аналізували за методикою К.В. Стороженко (2013): вимірювали нахил зубів, зокрема третіх молярів і других молярів відносно основи щелепи. На ОПТГ визначався дефріцит місця для третіх молярів, за методикою С.І. Дорошенко і Є.А. Кульгінського (2009). У процесі обробки даних вимірювань застосовували методи математичної статистики. Середнє значення й довірчий інтервал вибірки даних розраховували за вимогами стандарту ГОСТ Р 8.736 - 2011.

Проведені дослідження засвідчили, що чим більша різниця в нахилах третіх нижніх молярів відносно других, тим більше проблем у їх прорізуванні, оскільки вони прорізуються пізніше. Нижні треті моляри нахиляються коронковими частинами медіально і тому мають менші значення кутів нахилу відносно основи НЩ. Натомість верхні треті моляри при прорізуванні нахилені коронковими частинами дистально зі збільшенням величини кута нахилу відносно основи ВЩ. У 44 пацієнтів віком від 15 до 30 років 106 (60,2\%) третіх молярів знаходилися в стані ретенції: 35 (33,1\%) зубів у стані фізіологічної ретенції в осіб молодшого віку, $40(37,7 \%)$ - у напівретенції, а 31 (29,2\%) третій моляр - у стані стійкої ретенції.

Отже, проведені дослідження показали важливість диференційованого підходу до збереження третіх молярів, особливо при проведенні ортодонтичного лікування.

Ключові слова: ретенція, збереження третіх молярів, ортодонтія, положення зубів, зуби мудрості. 


\title{
TO JUSTIFY A DIFFERENTIATED APPROACH TO PRESERVATION OF THIRD MOLARS DURING ORTHODONTIC TREATMENT BY DETERMINING THEIR CONDITION AND POSITION IN THE JAW
}

\author{
Doroshenko S.I., Kuzmenko I.S., Storozhenko K.V. ${ }^{1}$, Irkha S.V., Demianchuk Kh.M. \\ Kyiv Medical University, Kyiv, Ukraine \\ ${ }^{1}$ O.O. Bohomolets National Medical University, Kyiv, Ukraine
}

\section{Summary}

No tooth is as problematic for patients as it is for third molars. After erupting later than all teeth, they often have little space in the dentition, or rather in the retromolar space, which should appear, above all, with further growth of the jaws. Therefore, the timing of their eruption varies considerably and is often accompanied by the appearance of significant morphological and functional disorders. That is why it is necessary to take a balanced approach to the preservation of third molars in the dental arch, providing them with a place in the retromolar space by timely detecting their condition and position in the jawbones and thus preserving the integrity of the dentition and implementing the fourth and last stage of bite raising in orthodontic patients with dental anomalies.

The purpose of the study. To substantiate a differentiated approach to the preservation of third molars in orthodontic treatment by determining their condition and position in the jaw.

Material and methods of research. For this purpose, 44 patients aged 15-30 years with different dentofacial anomalies having full permanent dentition including third molars confirmed by clinical and X-ray data were examined and given orthodontic treatment. Additional methods of the study included analysis of diagnostic model measurements (by Pont Korkhaus method). Furthermore, retromolar space was measured to find out if there is a space for third molars in the row of teeth by measuring its length and height using a silicone index (by S.I. Doroshenko and Ye.A. Kulhinskyi's method, 2009). X-ray studies included analysis of orthopantomograms (OPG), teleradiography (TRG), computed tomography (CT) scan, etc. The OPG analysis was conducted using K.V. Storozhenko's method (2013) which involved measuring the inclination of teeth, especially third and second molars relative to the jaw base. OPG showed a lack of space for third molars using S.I. Doroshenko and Ye.A. Kulhinskyi's method (2009). Measurement data were processed using mathematical statistics. The mean and the confidence interval for the data sample were calculated according to GOST R $8.736-2011$.

Results. The analysis of data showed significant variability in inclination of third molars relative to the jaw base and second molars on both sides of the jaws (on the left and the right). The largest difference in inclinations of third and second molars was observed in the lower jaw (LJ) both on the left and the right, with an insignificant deviation of $0.3^{\circ} \pm 0.2^{\circ}$, and the least difference was in the upper jaw (UJ), especially on the left, but with a larger deviation of $3.6^{\circ} \pm 0.2^{\circ}$

The conducted studies suggested that the larger the difference in inclinations of third lower molars relative to second ones is, the more problematic their eruption is, since they erupt later. Lower third molars incline medially at their crowns and therefore they have a smaller angle of inclination relative to the LJ base. While erupting upper third molars incline distally at their crown with an increased angle of inclination relative to the UJ base. In 44 patients aged 15-30 years, $106(60.2 \%)$ third molars were in retention, including 35 $(33.1 \%)$ teeth in physiological retention in younger people, $40(37,7 \%)$ teeth in half-retention, and $31(29.2 \%)$ third molars in constant retention.

An important factor in predicting the eruption of third molars became the presence of space for them in retromolar space, both sagittally and vertically. The presence of space in the row of teeth, i. e. sagittally, was observed in $25(14.2 \%)$ of 176 third molars: in LJ in $15(8.5 \%)$ molars, especially on the left in $7(4.0 \%)$, and on the right in $8(4.5 \%)$ teeth; in $\mathrm{UJ}$ in $10(5.7 \%)$ teeth $-6(3.4 \%)$ and $4(2.3 \%)$ respectively.

The presence of space for the third molars also depended on width at the equator, which appeared to be the smallest in UJ and varied from $10 \mathrm{~mm}$ to $15 \mathrm{~mm}$ with a mean of $11.7 \mathrm{~mm}$, and the largest in LJ - from 12 $\mathrm{mm}$ to $19 \mathrm{~mm}$, the mean was $14.17 \mathrm{~mm}$. Differences in the means between left and right UJ third molars were not detected $(11.8 \mathrm{~mm}$ and $11.8 \mathrm{~mm}$ respectively), and in LJ it was insignificant $(14.2 \mathrm{~mm}$ and 14.1 $\mathrm{mm}$ ). In individual cases, the difference was $2.0-4.0 \mathrm{~mm}$, and $1.0 \mathrm{~mm}$ in LJ. The latter confirms some scientists' conclusions that the sizes of upper third molars vary more widely.

Retention of third molars in the subjects was associated with different dentofacial anomalies most commonly reported in $17(38.6 \%)$ patients with distal occlusion (class II) and in $13(29.5 \%)$ persons with deep occlusion, and more rarely seen with medial (class III) $-4(9.1 \%)-$ and open occlusion $-4(9.1 \%)$.

Clinical studies suggested that when selecting a tactic for treatment of retained teeth, apart from determining their position in jawbones and the presence of a sagittal space in the row of teeth, it is also necessary to determine the size of vertical retromolar space for them which was measured using silicone indexes. Persons with deep and distal occlusion had the narrowest alveolar space from $0.5 \mathrm{~mm}$ to $4 \mathrm{~mm}$, while in those with neutral occlusion it was from $5 \mathrm{~mm}$ to $7 \mathrm{~mm}$.

Thus, the conducted studies showed the importance of the differentiated approach to the preservation of third molars, especially during orthodontic treatment.

Key words: retention, preservation of third molars, orthodontics, the position of teeth, wisdom teeth. 